\title{
The Fourth Industrial Revolution and the Sustainability Practices: A Comparative Automated Content Analysis Approach of Theory and Practice
}

\author{
Vasja Roblek ${ }^{1}$, Oshane Thorpe ${ }^{2}$, Maja Meško ${ }^{3,4}$, Mirjana Pejic Bach ${ }^{5 *}$ and Andrej Jerman ${ }^{6}$ \\ 1 Faculty of Organisation Studies in Novo mesto, Novo mesto, 8000, Slovenia; vasja.roblek@gmx.com \\ 2 College of Media and Mass Communication at the American University in the Emirates, Dubai, UAE; \\ Oshane.thorpe@aue.ae \\ 3 Faculty of Management, University of Primorska, Koper, 6000, Slovenia; maja.mesko@fm-kp.si \\ 4 Faculty of Organizational Sciences, University of Maribor, Kranj, 4000, Slovenia; maja.mesko@um.si \\ 4 Faculty of Economics, University of Zagreb, Zagreb, 10.000, Croatia; mpejic@net.efzg.hr \\ ${ }^{5}$ Ljubljanski potniški promet, Ljubljana, Slovenia; andrejjerman1@gmail.com \\ * Correspondence: mpejic@net.efzg.hr
}

Received: date; Accepted: date; Published: date

\begin{abstract}
Background (1) In the time of the 4th Industrial Revolution or Industry 4.0, a conglomerate of technical and social inventions, political contexts, socio-cultural circumstances, environmental policies, business models, and economic policies has emerged. Sustainability policy in theory and practice aims to deal with the effects of all these factors and to try to make decisions that ensure both social and economic development sustainably. The question is how to familiarize oneself with the current knowledge about the relationship between Industry 4.0 and sustainability?; (2) Methods: This research utilizes an automated content analysis method to analyses scientific journals, newspapers and magazines. The comparison of results of both research group shows that the scientific literature focuses more on changes in business models, production processes and technologies that enable sustainable development; (3) We found that the scientific literature focuses more on changes in business models, production processes and technologies that enable sustainable development. Newspapers and magazines articles write more about sustainable or green investment, sustainable standards and sustainable reporting. Newspapers and magazines articles write more about sustainable or green investment, sustainable standards and sustainable reporting. Newspapers, as well as some latest research journals, include articles of the COVID-19 outbreak and its effect on the economy and the environment. Indeed, the outbreak of the virus brings a new thought to the reorganization of the complex relationships between consumers, businesses and the state; (4) Conclusions: According to the comparison of the analyses of the results, it can is that the analyses of both types of literature, both scientific and professional, shows that there are common topics they write about, which are related to the field of clean production, emissions, renewable energy, climate change, sustainable investments and corporate sustainability. An urgent global issue that extends all over the world is the promotion of energy-saving technologies and reduction of carbon dioxide emissions.
\end{abstract}

Keywords: sustainability, Industry 4.0, automated content analysis, sustainable investment, corporate social responsibility, sustainable standards, sustainable reporting, smart manufacturing, renewable energy, cleaner production.

\section{Introduction}

In the second decade of the 21st century, we are facing with the emergence of the Fourth Industrial Revolution or Industry 4.0 (IR 4.0), as well as with the demand to implement the 17 Sustainable Development Goals (SDGs) set by 2030 written in Agenda for Sustainable Development. 
The Agenda balances the three dimensions of sustainable development - economic, social and environmental - and intertwines them among and stipulates that SDGs must be adopted by 2030 in all countries around the world [1].

Most of the scientific literature is described I4.0 primarily from a technical point of view [2], but there are less researched topics like organizational management [3-5], as well as the ecological and social aspects within I4.0. Birkel et al. [6] point out that there is still rare integrative researches of economic, ecological and social aspects. It is tough to simultaneous maintaining economic profitability and improving the environmental and social aspects of industrial value creation. Thus, the challenges and potentials of I04 appear contradictory in each of the three dimensions of the Triple Bottom Line. The I4.0 concept raises fears of job losses and growing inequality. Therefore, an interdisciplinary and integrative study of I4.0 is required, which not only balances ecological and social potentials but also connected them to market success $[7,8]$. However, the question is, how could be used I4.0 to address the burning issues of SDGs?

In the search for an answer to this question, research focuses on the elements of I4.0, based on which sustainable development in the economic, social and environmental fields has been achieved over the last ten years. The opportunities offered by I4.0, through the improvement of production processes and the introduction of robotics in processes, have stimulated reflection on how all this will affect the situation outside the smart factories themselves $[9,10]$. There are ten major global trends in I4.0, most of which already exist but have been improved, in terms of the features introduced: demographic shifts, urbanization, knowledge growth, deindustrialization, market globalization compared to protectionism, advanced business models, technology convergence, increase robotics, cybersecurity, climate changes and global sustainability [11,12]. The immediate sustainability result of I4.0 is manufacturing-economic sustainability. The digitalization of the manufacturing industry influences manufacturing efficiency, supply chain merging, energy efficiency the emergence of business model innovation, cost-saving, financial sustainability, human resource skills development and corporate profitability. It is vital for changing fossil fuels with renewable energy which has for consequence decarbonization of the society. I4.0 is so eventually crucial for promoting and enabling environmental protection and emission reduction [13]. Since there are a large number of articles, both empirically and a priori drove, these span cases of scientific enquiries as journal articles and others span newspapers and magazines. In this research, an alternative approach was chosen that was capable of efficiently and successfully categorizing vast quantities of data, and enabled the reader to obtain appropriate explanations of the research phenomenon understandably. For the topic under discussion, an automated content analysis method was used to identify the key themes and the concepts of interest to the researchers [14,15].

This paper consists of the following sections. After the introduction, the research method is followed, which includes data collection and literature selection. The fourth chapter provides data analysis and the results of automated content analysis. The paper concludes with a discussion of results and conclusions, which include a comparative analysis of findings, research limitations and propose researches in future.

\section{Materials and Methods}

\subsection{Data Collection}

This research presents an insight into the studies about the relations between I4.0, emerging changes to the economy, production, sustainability and the environment. In the study were analyzed academic journal articles published from 2010 to June 2020 and news and magazines articles published between 2015 and 2020. I4.0 has influence on the emergence of new technologies and business models, and it has an essential impact on social development. In order to know the problems and the current situation, which also affects the society, not only the companies, it is necessary to observe and analyses news articles that reflect a broader spectrum of trend events, as it can be said in jargon "what is going on" [16]. In this way, "hot themes" from a particular area are to be designed and presented to the public and achieve an "agenda-setting" effect [17]. Newspaper articles bring to 
the attention of the public those news items that are of interest to them at the time and that could influence changes in regulatory policy and practice $[18,19]$. The purpose of academic scientific articles is to present new scientific findings and thus to provide the scientific and professional public with access to further knowledge in a particular scientific field [20].

\subsubsection{Literature Selection}

The literature selection was prepared in the three-step screening process. First, the papers were searched by keywords on Industry 4.0, $4^{\text {th }}$ Industrial revolution, sustainability, clean production, sustainable development, environment, green investment, smart factory, corporate sustainable responsibility on WOS database. In the second phase, only peer review papers were selected. The third step includes manual review and selection of peer review papers titles, abstracts, and conclusions.

The research platform Web of Science was used for the search Science Citation Index Expanded (SCI-EXPANDED), Social Sciences Citation Index (SSCI) and Arts \& Humanities Citation Index (A\&HCI) to identify relevant papers. The Boolean keyword combination was used to search for the relevant papers $(\mathrm{TS}=$ (Industry $4.0 *$ AND sustainability) AND LANGUAGE: (English) AND DOCUMENT TYPES: (Article)Indexes = SCI-EXPANDED, SSCI, A\&HCI). The time frame was set from 1990 to 2020. The results of the search were limited to the articles published in the refereed journals only. The peer review was limited to scientific journals written in English and was therefore not intended to provide a comprehensive assessment of the totality of the state of the subject.

In this paper is used the literature review for analyzing the current state of art of particular topic and to identify research gaps for preparing future researches [21]. The literature review is preparing according the Prisma 2009 technique. The process is presented in figure 1 [22].

A search of the Web of Science yielded 210 articles published in 92 peer-reviewed journals, the authors' analysis utilized data from Clarivate Analytics, the Web of Science database. Review of the abstracts as well as the full texts was undertaken, unearthing 37 irrelevant articles, i.e., those that the main text was incongruent with the inquiry into the Industry 4.0 impact on sustainability were subtracted from the sample and analysis, which resulted in a final sample of 173 articles published across 77 journals.

Among the leading scientific journals that publish research with I4.0 and sustainability/sustainable development in the last ten years (the first article was published in 2010), are Journal of Cleaner Production, International Journal of Production Research, Journal of Manufacturing Technology Management, Sustainability, Process Safety and Environmental Protection, Computers Industrial Engineering, Production Planning Control, International Journal of Production Economics, Technological Forecasting and Social Change and Journal of Business Research. Most of the papers come from the WOS categories of the environmental sciences (61), green sustainable science technology (57) and environmental studies (43). These categories are followed by the engineering industrial (32), engineering manufacturing (30), engineering environmental (24), operations research management science (19), management (12), computer science interdisciplinary application (10) and energy fuels (9).

The newspapers and magazine articles were taken from the ProQuest recent newspapers database and global news stream. These two databases are considered to deliver complete news coverage [23]. The ProQuest recent newspapers include 50+ current edition digitized newspapers, and global news stream contains indexed and entirely stored articles from more than 2,500 national, regional, national and international English newspapers [23]. The option to eliminate duplicate news has been added to the search. When saving essential information about the source of the article (issue date, the title of the newspaper) was automatically captured. The search returned 110 articles from magazines and newspapers in the English language. All articles were published between 1 January 2015 and 16 June 2020. Among the leading newspapers and magazines selected were The Times, The Wall Street Journal, The New York Times, The Financial Times, The Economist, Reuters and The Guardian. 


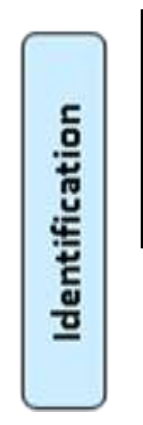

Records identified through WOS (SCI,

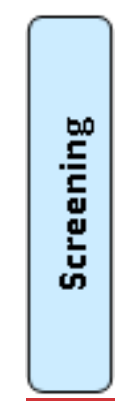

SSCI, A\&HCI) database searching $\left(\mathrm{n}_{1}=210\right)$

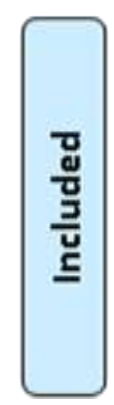

Records after duplicates removed $(\mathrm{n}=0)$

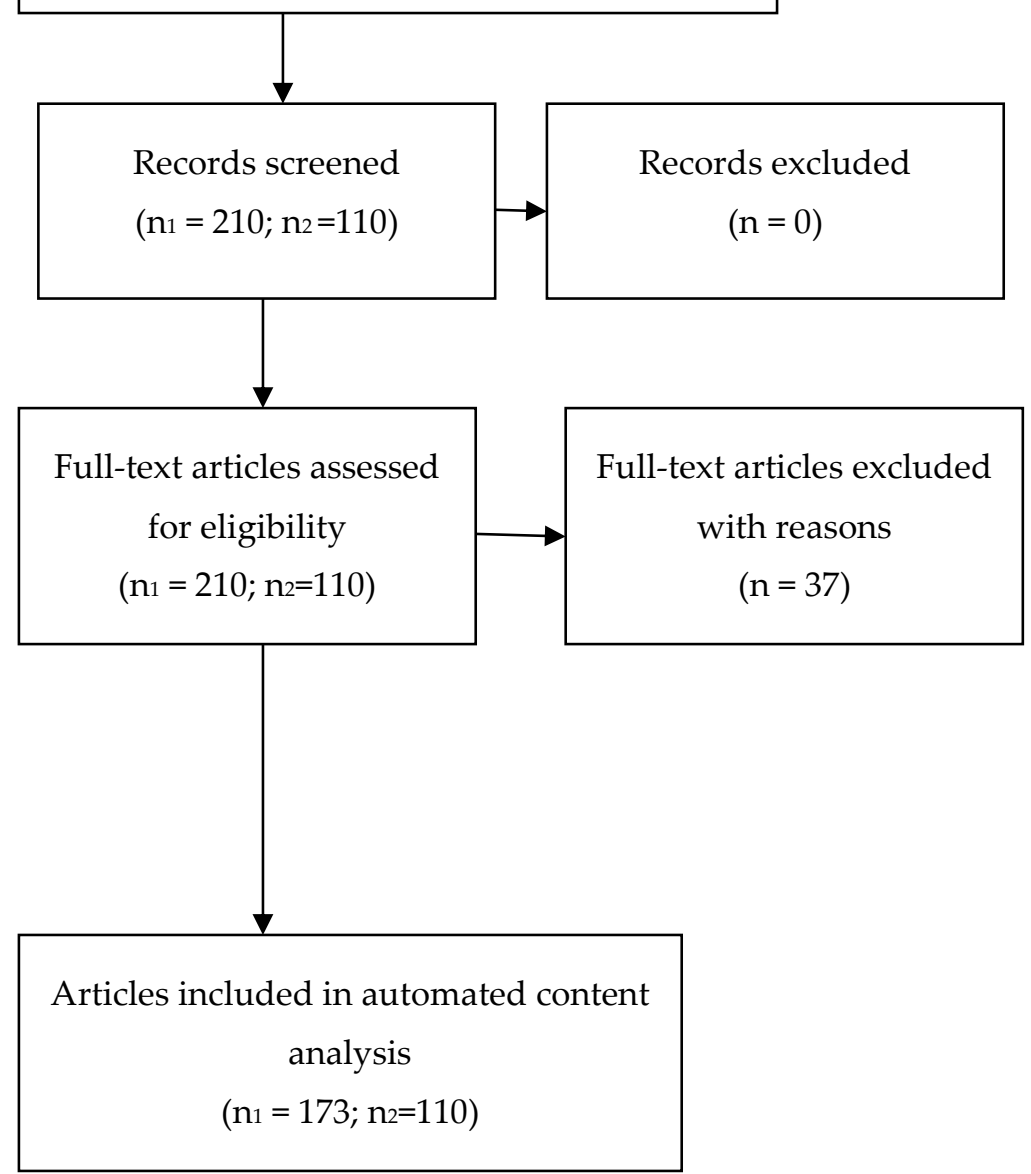

Figure 1. Prisma 2009 flow diagram

\subsection{Method: Automated Content Analysis}

The automated content analysis is using in this research for the content analyses of the articles, which is based on algorithms that use probabilistic models $[15,24]$. The automated content analysis represents a text-mining tool [25] and it is used for the analysis of text and machine learning as a branch of computer science, which focuses on pattern recognition and data prediction and the identification and definition of thematic/themes in the selected text collection (terms) [26]. The method uses a set of statistical algorithms that can identify and describe the concepts/themes of a large number of texts [27]. Therefore, this method is comparable to the feature- or object-based classification in remote sensing [28]. The terms discovered by this method are defined as groups of words that are strictly related in literature and therefore, probably represent a common theme or concept [29]. These terms are then used as categories to sort the research literature. The use of concepts for classifying text distinguishes this process from a simple number of word frequencies (e.g. word senses, wordnet) because it can take into account semantic and linguistic complexities such as synonyms, co-decision frequencies, and sentence structure [30]. 
The software, Leximancer Text Analysis Tool 5.0., was used for implementing the automated content analysis. Leximancer 5.0 automatically analyses text documents to provide key thematic and concepts from the text. It is described in the next subchapter.

\subsection{Data Analysis}

In our work we use the text mining approach [31], utilizing automated content analysis. The data was analyzed using Leximancer 5.0, a high-level natural language processing software. The Leximancer does not use the coding of expressions or word frequencies and phrases, but analyses the meanings in text extracts based on its algorithms following the extraction of the most important concepts and ideas. To conduct qualitative analyses, it uses the quantitative method with different algorithms for the phrases [32].

The analysis was carried out in four steps. The first step involved the selection of the document, the second step involved the generation of concept seeds, the third step involved the creation of a thesaurus, and the fourth step enabled the generation of the results. Each step can be adapted to the needs and requirements of the research. In detailed research, all the words that were not meant for the content of the research were excluded. Leximancer already contains a stop word list for individual words (e.g., a, an, me, you, via). The remaining words were manually removed from further analysis (e.g., "paper", "article", "study", "research", "methodology").

In the next subchapter, the research results are presented.

\section{Results}

\subsection{The thematic concerning in the scientific journal's articles}

Leximancer generated a total of 20 concepts and five themes from the titles, abstracts and keywords of 172 articles published in 77 journals. The authors used the slider \% visible concepts to $100 \%$ and changed the number of concepts visible on the map from 50\% (automatically) to $100 \%$. The theme size was moved from $33 \%$ (automatic) to $61 \%$. A theme is defined as a group or cluster of concepts that have commonalities or connections, which are seen in their immediate proximity to the concept map. The names of the themes are those of the most prominent concept in the group of connected concepts [15]. Table 1 presents the themes, hits and related concepts.

Table 1. Themes and concepts in the journals in the years from 2010 to June 2020

\begin{tabular}{ccc}
\hline Theme & Hits & Concepts \\
\hline Sustainability & 435 & sustainability, industry, manufacturing, management, supply, data, industrial, waste \\
Technologies & 252 & technologies, energy, systems, efficiency \\
Model & 239 & model, process, production, business, development \\
Environmental & 114 & environmental, performance, economic \\
Emissions & 38 & emissions, carbon, consumption \\
\hline
\end{tabular}

Source: Authors' work.

Figure 2 shows the related concepts that are connected to the themes, which are presented in circles. Themes on a Leximancer concept map are heat mapped, and this means that hot colors (red, orange) denote the most important themes, while cool colors (blue, green) denote those less critical [32]. The four themes with the most significant number of hits are "sustainability", "technologies", "model" and "environmental". 


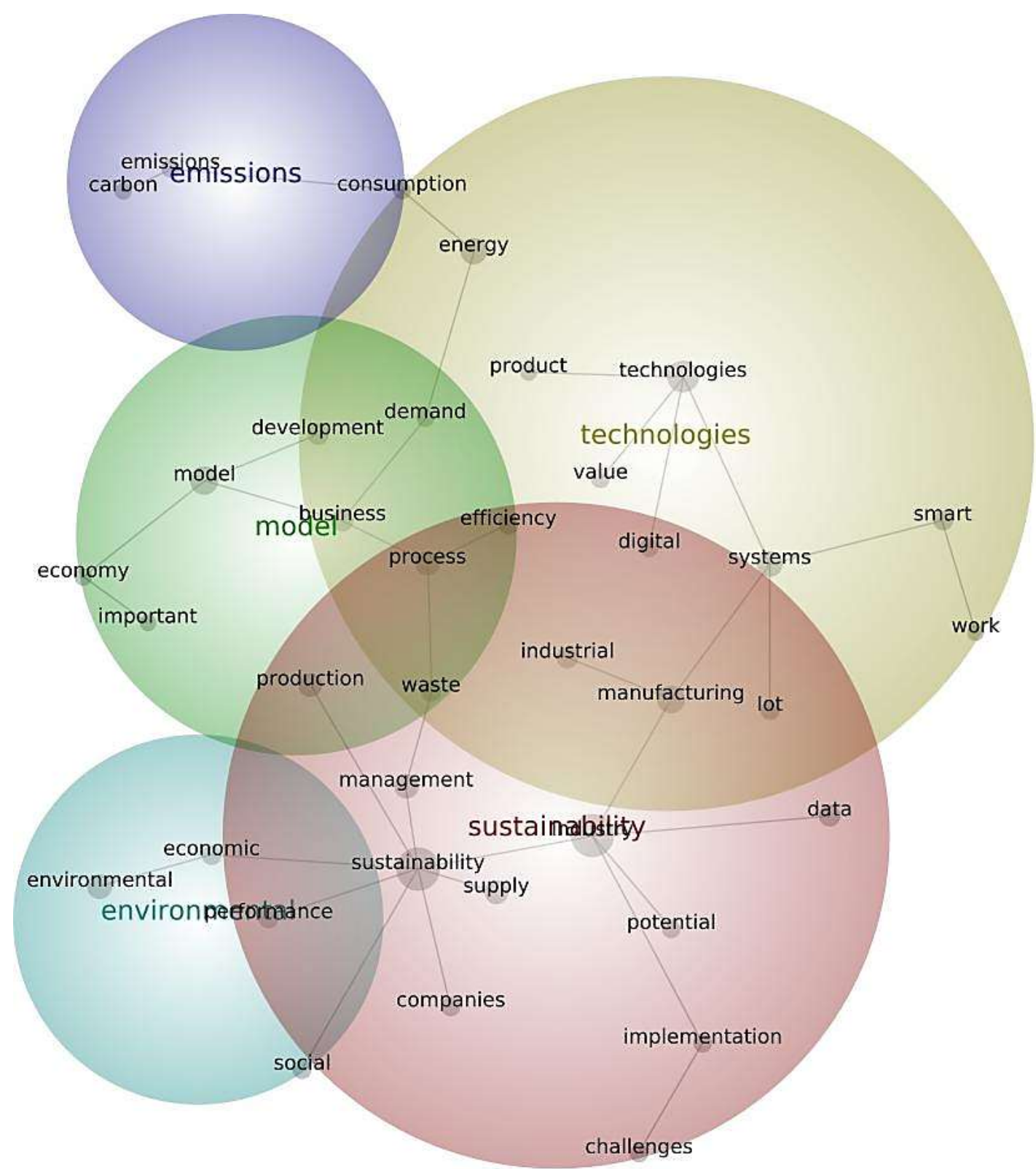

Figure 2. Concept map of the chosen scientific journal papers published between 2010 and June 2020 Source: Authors' work.

Figure 2 shows that the circles of specific themes overlapping with the circles of other themes, thus forming cross-sections that contain individual concepts, which thus fall into both overlapping themes. For example, the theme »sustainability « overlaps with the themes »environmental «, »model « and »technologies«. The theme »technologies « overlaps with the themes »emissions«, »model« and »sustainability«. The theme »environmental« overlaps with the themes »sustainability « and »model«. The theme »model« overlaps with the themes »environmental «, »sustainability « and »technologies«. The theme »emissions « overlaps with the themes »technologies« and »model«. It can also be seen in Figure 2 that the concepts »waste«, "production«, "process « and »efficiency « lie between the intersection of the themes »sustainability « and »model«. The concepts »social« and »performance« lies between the intersection of the themes »environmental « and »sustainability«. The concept "potential" lies between the intersection of the theme's "development" and "services". The concepts »manufacturing ", »internet of things" " »industrial « and »digital « lie between the intersection of the themes »sustainability « and »technologies«. The concept »consumption« lies between the intersection of the themes »technologies« and »emissions « and the concepts »business«, »demand «, »efficiency «, 
»process«, »waste« and »development« lie between the intersection of the themes »technologies« and $»$ model $\ll$.

\subsection{The thematic concerns in the newspapers and magazines articles}

The authors used the slider \% visible concepts to $100 \%$ and changed the number of concepts visible on the map from $50 \%$ (automatically) to $100 \%$. The theme size was moved from $33 \%$ (automatic) to $53 \%$. A theme is defined as a group or cluster of concepts that have commonalities or connections, and it is seen in their immediate proximity to the concept map. The names of the themes are those of the most prominent concept in the group of connected concepts. For each theme, the number of hits was calculated based on the number of text excerpts that fit each concept [15]. Table 2 presents the themes, hits and related concepts.

Table 2. Themes and concepts in the journals in the years from 2015 to June 2020

\begin{tabular}{ccc}
\hline Theme & Hits & Concepts \\
\hline Sustainability & 1825 & $\begin{array}{r}\text { sustainability, investment, ESG, environmental, financial, market, social, investors, Asia, } \\
\text { priorities, green, research, management, report, corporate, products }\end{array}$ \\
\hline Energy & 1098 & energy, change, climate, global, impact, supply, industry, renewable, risk, economy, emissions \\
\hline Business & 991 & business, data, cities, technology, development, intelligence, government, growth, services \\
\hline Companies & 681 & companies, work, standards, workers \\
\hline World & 394 & world, people, power \\
\hline Oil & 98 & oil \\
\hline
\end{tabular}

Source: Authors' work.

Figure 3 shows the concept map of the papers on a more detailed level. The four themes with the most significant number of hits have »sustainability«, »energy«, »businesses« and »companies«. 


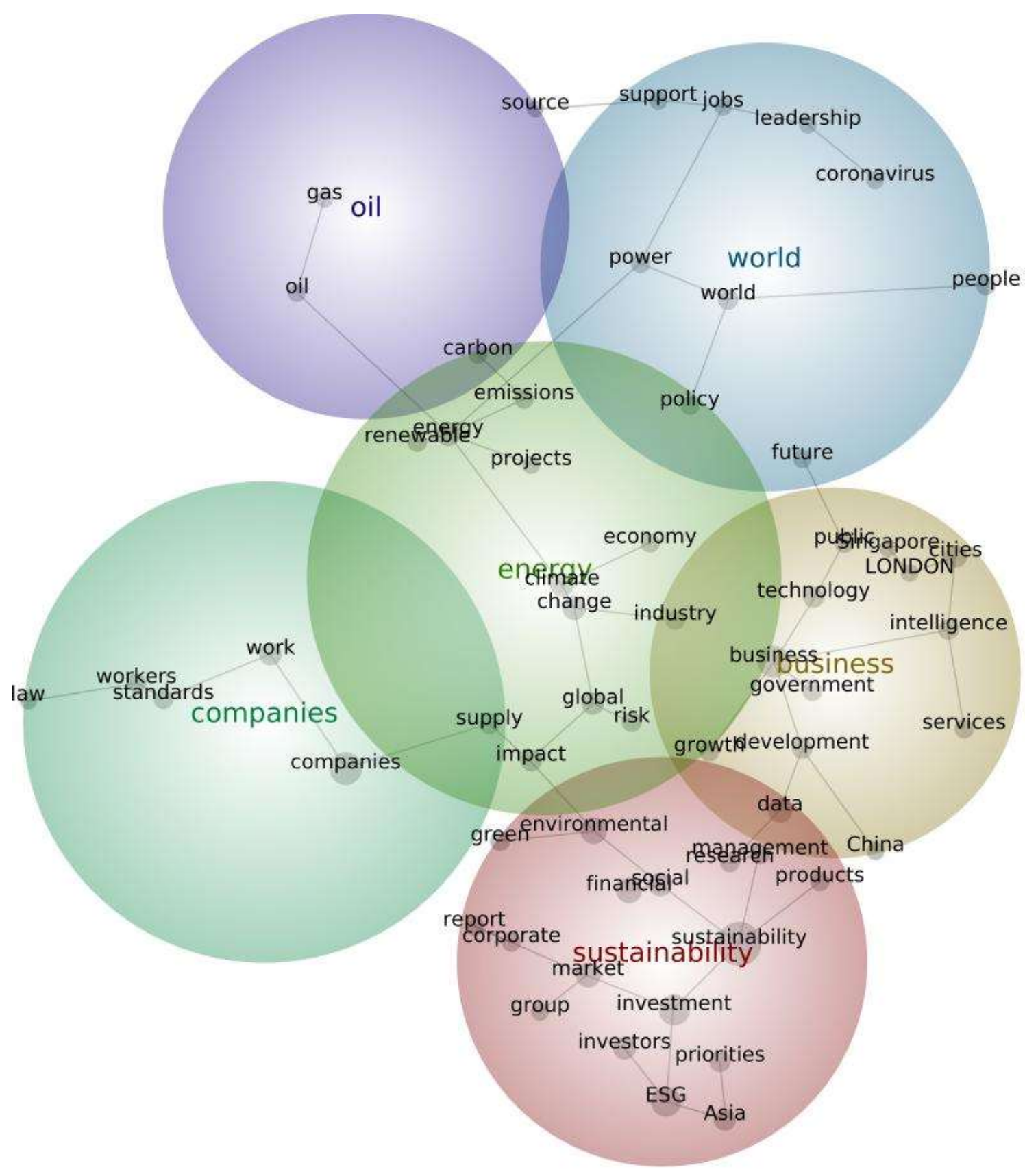

Figure 3. Concept map of the chosen newspapers and journals articles published between 2015 and June 2020

Figure 3 shows that the circles of specific themes overlapping with the circles of other themes. For example, the theme »sustainability« overlaps with the themes »energy « and »businesses«. The theme »businesses« overlaps with the themes »sustainability« and »energy«. The theme »energy« overlaps with the themes »sustainability«, »businesses«, »companies«, »oil« and » world «. The theme »companies« overlaps with the theme »energy«. The theme »world « overlaps with the themes »energy« and »oil« and the theme »oil« overlaps with the themes »world « and »energy«. It can also be seen in Figure 3 that the concept »data « lies between the intersection of the themes »sustainability « and »business«. The concept »industry« lies between the intersection of the themes » business « and »energy«. The concept »policy« lies between the intersection of the themes »world « and »energy«. The concept »carbon « lies between the intersection of the themes »oil« and »energy«, and the concept »supply« lies between the intersection of the themes »companies« and »energy«. 


\section{Discussion}

\subsection{Research theme through the research source characteristics}

In the first part of this chapter, papers from the scientific journals are analyzed, followed by papers from the newspapers and journals are analyzed.

\subsection{Research theme from scientific journals articles}

Based on the primary concepts that can be derived from the analysis of scientific journal articles, it can be concluded that the five themes (see Figure 2), regarding the treatment of I4.0 and sustainability with a focus on technology, clean production and the environment are: sustainability, technologies, model, environmental, and emissions.

The manufacturing sector (theme sustainability and technology) is undergoing fundamental transformations [33] focusing on reducing greenhouse gas emissions and waste generation by implementing the low-carbon and recycling technologies in order to enhance sustainability [34]. I4.0 affects the sustainability aspect of manufacturing, but not only the ecological aspect (i.e. renewable energy, resource efficiency), but also technical, social, and organizational aspect of sustainability [35]. The central paradigm within the technical aspect of I4.0 is the Internet of Things which is evolving together with the Internet of Space in the Internet of Everything. Internet of Things plays a crucial role in connecting a variety of everyday objects to the Internet. Internet of Things applications have become indispensable in the areas of communication, service provision, information, and process management. They can be encountered in the areas of intelligent or smart cities, healthcare, agriculture as well as industry and production. For example, the implementation of information and technology systems in agriculture through the intensive use of data can improve agricultural productivity [36]. Informatization in I4.0 enables us to monitor and control the physical world with the help of information technology. The exponential growth of connected devices, the heterogeneity of Internet of Things applications and the diversity of network technologies raise concerns about the sustainability of Internet of Things. Solutions are sought by introducing a decentralized Internet of Things platform and controlling the Internet of Things environment during implementation, monitoring the quality of the system and making efficient use of available resources. Such solutions are necessary to improve and maintain the Internet of Things of the future and all its applications, including the Industrial Internet of thing [37].

The basis of the development paradigms of I4.0 is the digitalization, informatization and connection of industrial and other social processes. The development and establishment of data analysis, machine learning and artificial intelligence, as well as business operations, is crucial for the implementation of the processes, which will also affect the emergence of the potential of all three dimensions of sustainability (Triple Bottom Line concept of sustainability). I4.0 enables the Triple Bottom Line by improving productivity and product quality [38]. The technological transformation enables the emergence of the cyber-physical principles which arose as a result of the informatization processes of transformation in manufacturing, logistics and supply chain [39]. In recent years, manufacturing and research in this field are oriented towards digitalization, informatization, data analysis [40,41], and the exposure of the digital twins [42], what can help to identify real-time events and predict future events.

Manufacturing companies are also faced with the need to reorganize their supply chains in line with United Nations Sustainability Goals and market situation (e.g. in doing so, they are following various practices such as lean, green, circular and I4.0 which lead in finding value chain partners that meet both sustainability criteria and the required technological know-how [43]. Manufacturing (economic aspect) continuously monitoring energy consumption, environmentally sound manufacturing (e.g. implementing technologies that enable cleaner production, use of renewable energy and reduction of pollution from changing polluting raw materials with alternative environmentally friendly materials (ecological) [44,45], and a safer working environment and less intensive workload, job enrichment and social equality (social) [46]. It can be concluded that due to sustainable production, I4.0 prove its benefit for societal development [35]. For example, I4.0 can 
improve social welfare with corporate sustainability activities [47]. The organizational aspect of sustainability starts with the organizational culture comprising sustainability vision, mission, and values [48]. It is also important that business strategies are sustainable [49] and that the main drivers of I4.0 can generate high triple bottom line profits (environmental-economic-social) in emerging markets, which is becoming a significant factor in emerging markets because they still use unsustainable approaches: child labor, exploitation of workers, use of fossil fuels, inadequate environmental legislation allowing the use of obsolete ecologically questionable technologies and raw materials [50].

From these reasons, I4.0 is reshaping business models and production processes of the organizations fundamentally [51] (theme model). The traditional business model in the manufacturing sector is changing. Production processes are oriented toward energy optimization and reuse and recycle wasted material [52]. Adopting a novel approach to business modelling is, therefore, mainly focused on business process automation (adaption of I4.0) and principles of circular economy [53]. Digital and connected manufacturing technologies are the main enabling factors for new business models.

Moreover, I4.0 also requires the alignment of the business models of other organizations within the ecosystem [54]. Digital platforms are an essential business model within I4.0 platforms, and they are emerging in different sectors, including retail, education, healthcare, transport, aggrotech, fintech and real estate. These platforms are characterized by the fact that they change the labor market with the emergence of non-standard forms of work, from platform work to freelance work. Platform work is characterized by mass work, which can also be offered from home. This was particularly important during the outbreak of COVID -19 when quarantine forced many people to stay at home. This period showed how important digital platforms are for global achievements (e.g. work, study, health, businesses) and how they can be used better and sustainably [55].

For a company, business models represent a form of timely reaction to market requirements. The markets are changing fast, and companies are managed and organized, and their supply chains are also changing. Markets are becoming more dynamic with the new digital technologies, as evidenced by the fact that the average lifetime of a company listed in the S\&P 500 has fallen from 60 to 18 years. Companies can thus establish themselves in a short time [56]. Business models are also being adapted concerning the way production processes and supply chain organization are designed. For example, the digitalization of production processes, together with the connection of smart devices and systems, enables real-time control and enables fast, decentralized decision-making [57]. The advantages of virtual and augmented reality technologies are increasingly used to optimize production processes. Simulations aim to prevent the occurrence of bottlenecks in advance and to save time. Shorter production lines are also to be achieved through additive production [58]. Sustainable business models promote transparency and change consumer behavior by involving consumers more closely in the creation of new products and services. I4.0 thus encouraged a shift from mass production to personal (individual) centralized manufacturing. The manufacturing transformation encourages factories to use digital and information technologies (mass data, cyberspace, artificial intelligence) and to adapt their methods of advertising, delivery and customer service, product design, manufacturing or testing [56].

Economic performance, such as production efficiency and labor productivity, tends to be the immediate outcome of I4.0, which will transform future manufacturing and business models for sustainability [13] (theme environmental). The transformation will change the dominant linear economic model into economic sustainability. For instance, renewable energies and the use of existing, but currently unused energy resources (e.g. geothermal energy), can potentially play a decisive role in improving regional development. It can especially influence regional economies since regional value creation (monetary aspects, cost reduction, increase in purchasing power, job creation, tax revenues, social, ecological and ethical aspects, and improved vitality) is remarkable if all the financial funds remain in the region [59]. The mining industry represents the second case where the introduction of sustainable environmental criteria has a significant impact on the economy, the environment, water pollution and social issues in the mining environment. For these reasons, it is 
essential for the global mining industry in terms of how it will deal with sustainability. Ranangen and Lindman [60] for example, based on research in the Nordic mining industry, recommend that it should follow sustainable guidelines in the areas of corporate governance, fair business practices, economic aspects, human rights, labor practices, society and the environment.

The manufacturing sector is a high polluter of greenhouse gases, mainly carbon emissions (theme emissions), which affect the global environmental sustainability and contributes to extreme weather conditions and pollution [61]. In order to reduce air pollution, some countries implemented carbon tax levies (for this reason, organizations have the motive to implement the green technologies (e.g. energy-saving and low-carbon technologies) $[62,63]$. The pollution is only one of the reasons why it is vital to introduce new business models in industries like shoes, textiles or metals. It tackles labor shortages, the need to control costs and environmental issues related to carbon emissions. These are the reasons that are forcing the footwear industry to change its production model towards manufacturing highly competitive products. At the same time, all manufacturing industries require higher costs for them to introduce carbon tax rates, so companies should be interested in faster investments in low-carbon technologies [63]. In the field of corporate sustainability, raising the importance of sustainable reporting, which includes information on the environment, society and governance (ESG), is becoming increasingly important in the financial markets. There is a risk that by reporting on sustainability, companies are planning a speculative effect on the value of their shares at the time of publication. The last challenge is a challenge for policymakers in formulating rules for ESG reporting. They point out that the purpose of the rules must be to ensure that transparency is value-relevant; the findings indirectly support the view that ESG reporting is likely to improve market efficiency and strengthen the growing confidence of investors, companies, institutions and practitioners in the materiality of ESG information [64].

\subsection{Research theme from newspapers and magazines articles}

After conducting an automated concept analysis of (see Figure 3) magazine and newspaper articles with the content on I4.0 and sustainability, focusing on technology, clean production and the environment, it is possible to identify and explain the most critical and recent global socio-economic and technological trends.

Concern for the environment and people's demands for environmental protection (theme world) came to the fore with the development of socially responsible movements in the 1960s. Nevertheless, the natural and urban environment is increasingly threatened by the effects of weather. In Singapore, for example, they face rising sea levels and rising tropical temperatures. The outbreak of the COVID-19 pandemic in 2020 confronted city with an increase in waste throughput of up to 40 per cent of normal levels. At the time of the pandemic, people stayed at home, which led to an increase in the amount of waste, which consisted mainly of food packaging waste. However, the COVID-19 pandemic in 2020 became an indicator of the impact of human lifestyle and business activities on the environment. Declining economic activity and increased homeworking have led to falling carbon dioxide emissions. Analysts estimate that carbon dioxide emissions could fall by more than 4 per cent in 2020 compared to 2019 as a result of the pandemic. If this reduction had remained constant each year during the decade, it would still not have achieved the 7.6 per cent annual reduction needed to meet the 1.5-degree Celsius global warming target. Based on these results, we see that even repeated shutdowns of countries cannot slow down climate change. How can this be achieved through individual measures such as reduction, reuse and recycling? The second problem, which is also evident in Singapore, is that their government is trying to develop sustainabilityoriented environmental programs. At the same time, other Asian neighboring countries are not aware of the environmental problems because they have no regulated legislation in the field of 
environmental protection and even less suitable environmental projects supported by local governments [65].

Based on the theme of sustainability, it can be stated that the policy of investing in sustainable projects in the ESG sector represents an important measure of confidence of companies in sustainable projects, and investors in research and development capacities of companies and countries that promote sustainable investments [66]. Over the last decade, passive assets and responsible investment have stimulated the growth of passive sustainable funds. They have promoted active equity activities with passive fund providers not only in Europe and the United States (US) but this investment area is also gaining ground in Asian countries. In the period after 2015, the US even denies the importance of sustainable environmental protection and rejects United Nations Agenda 21. The US government administration did this because, in their opinion, it was prepared to weaken the economic interests of both companies and the state (e.g. Trump administration withdraws from the US Paris Climate Agreement, stops Obama's Clean Power Plan and the reopening of coal mines, reduces the importance of toxic air pollution regulations) [67].

The European Union (EU) is aware of the importance of developing a green investment. The EU is, therefore, encouraging the issuance of green bonds, which are playing an increasing role in financing the investments needed to make the low-carbon transition a success. However, due to internal disagreements between members on whether nuclear energy is a sustainable energy source, there are currently no common European rules for green investment in the EU. These rules will define what is considered a sustainable investment. The rules will, therefore, cover all types of energy, including nuclear energy. Coal investments will be excluded from any sustainability definitions following the rules. The rules will make it possible to communicate how investors deal with assets such as green bonds, bank loans and investment products. The rules will help to eliminate the socalled "greenwashing" that occurs when countries and companies want to show their environmental capabilities in a better light than they are. Once the rules are adopted, it is expected that more capital will be redirected to activities that are consistent with the Paris climate convention. The rules are expected to take effect in 2021 [68]. The upturn in ESG in Asia in recent years has been driven by increased regulatory pressure in the context of environmental protection targets (e.g. China). Analysts see another reason in the increasing investment by Japanese and Thai state pension funds in sustainable projects, as they have identified potential growth in ESG approach in the region. It was the state pension funds that also increased the interest of other investors in the region in ESG. National and multilateral development banks have also taken an essential step in the field of ESG by adopting rules. Regulation of the ESG has also been undertaken by capital market regulators (both government agencies and the stock exchange themselves). Over the past three years, both investors and companies in the region have become aware of the importance and promotion of principles of responsible investment (PRI), as the significant problem with ESG is the often-subjective investment ratings. As a result, there have been frequent abuses in recent years in cases of nonsufficient corporate reporting on sustainable development. Investors point to the problem of lower quality and inadequate data, which makes it impossible to make well-considered investment decisions. In Asia, despite the extremely fragmented regulatory environment, they perceive the importance of ESG approach to promote values and ethical principles, but not the financial value or returns themselves. ESG has thus influenced ethical investment to provide a framework for sustainability not only at the planetary level but also at the corporate level. In this way, non-financial factors, such as social and 
environmental factors, have gained the potential to influence the value of shares and the goodwill of the company itself. It has become essential for ESG to influence risk-adjusted returns [69]. However, time will tell, based on an analysis of stock market indices and the value of company shares, whether the choice of ESG strategy has contributed to better business results. The companies have to ensure that their sustainable corporate reports include quality data about their exposure to climate change risks. In the field of sustainable corporative reporting is expected that will initiatives such as the EUs taxonomy provide a better definition of sustainability and thus help companies to ensure the right data for reporting. It is also expected that the Global Task Force on Climate-Related Financial Disclosures will control the corporate sustainability reporting, which will reduce investment risks and stabilize the ESG market in the future [70]. Awareness of the importance of sustainability and corporate social responsibility is also in line with customer expectations and attitudes. Research on consumer behavior shows that consumers do not reject products or services based on price and quality preferences. Modern consumers are increasingly aware of the importance of social and moral values, and the consequences of this awareness are visible in the extraordinary growth of the global market for organic and environmentally friendly products, which have well-known and socially responsible members of the supply chain [71,72]. Socially responsible companies work without plastic packaging and sell products without animal testing, without leather (except in the form of reuse), without genetically modified food, without palm oil and its environmentally deleterious reputation, the aim is to offer completely natural products for the health of their customers. Consumerism is thus increasingly associated with people's social-ethical behavior and awareness [73].

Regarding themes of energy, oil and companies, the following can be concluded. In 2019 and 2020, global investment companies, banks and state pension funds (e.g. Credit Suisse, Deutsche Bank, the Dutch Fund) announced a reduction or even a withdrawal of investments from fossil fuel production (thermal coal mining, oil production from tar sands). Companies have become aware of the importance of sustainable financing and are shifting their investments to sustainable projects $[74,75]$. The use of renewable energies and clean energy is increasing, but the demand for oil and gas is expected to continue for decades to come. The change in the field of reducing the carbon intensity of energy is taking place as a result of pressure from investors, growing consumer awareness and governments adopting stricter environmental legislation due to climate change. For example, California will ban the use of diesel trucks from 2045 [76].

Global markets are changing due to the emergence of new clean technologies, sustainable materials, work standards and the awareness of customers and companies of the sustainability of production and consumption. Companies (from the food industry to the fashion industry) are preparing plans to reduce their carbon dioxide emissions, eliminate disposable plastics in packaging and sustainably sell more products (e.g. digital platforms) [77]. In the field of agriculture, too, increasing attention is being paid to sustainable principles. For example, farmers are moving from conventional to ecological practices, which involves reducing the excessive use of fertilizers and thus preventing nutrient depletion of the soil. They are investing more and more in technology and work processes, with the result that pesticides and fertilizers are being displaced from production processes. Drones with sensitive sensors and software are already being used in the agricultural sector, which can predict potential problems due to the health of the soil or the plants themselves, vegetables, vines. The results of using cleaner technologies and smarter equipment are healthier soils, 
healthier agricultural products, higher yields per hectare and a significantly reduced ecological footprint [78].

It is predicted that the development of sustainable measures will have an impact on future commercial success. The sustainably conscious have set themselves the goal of becoming "carbon neutral" along the entire value chain (production, packaging, logistics). Companies are increasingly turning to the use of renewable energies and are switching their logistics to electric vehicles and drones for delivery. Carbon netting, which results from the integration of sustainability standards into business processes, thus enables the financing of emission reductions in other areas, such as the prevention of deforestation. Due to the growing demand for sustainable and ethically produced products and services, companies have begun to create brands that emphasize product relevance under international standards for social, environmental and animal welfare practices $[77,79]$.

The technological development in I4.0 requires oil companies to diversify their investments and reinvest in solar power generation in recent years (after a failed investment cycle at the beginning of the 21st century), buy companies to sell electricity to electric vehicles, take over power utilities and even invest in projects such as floating wind farms [80]. However, it is also necessary to be aware of the consequences of the transformation in the field of abandoning internal combustion engines and replacing them with electric vehicles and probably also with hydrogen-powered vehicles and other options that are still being developed in the laboratories today. Leaders in the automotive industry face the challenge of building the car of the future. They are expected to act responsibly in the context of change, the consequences of which will be visible in the short term as the disappearance of traditional roles in the automotive industry and its supply chains. Supply chains could be reduced by 20 to 30 per cent, which in turn would mean a loss of 20 to 30 per cent of jobs. It is estimated that by the end of the I4.0 (around 2030), one-third of the workforce in the automotive industry will become redundant. In terms of production, this will be the most significant change in history. Companies will also need to redesign their supply chain management, procurement and human resources management [81].

Chocolate manufacturers are one such example. They are aware that consumers are increasingly demanding products of ethical origin from chocolate products. They are, therefore strengthening all their sustainability programs, which have so far had only a negligible impact on reducing child labor in cocoa production in West Africa. The company Nestle decided in 2019 to invest in the promotion of sustainable cocoa extraction in the supply chain in West Africa. The company will begin to reduce the number of underage children working in cocoa supply chains. Together with the International Cocoa Initiative, it aims to eliminate child labor in Côte d'Ivoire by 2025. In doing so, they expect government support to promote the training of farmers and other programs to address this problem [82]. Humankind has been used to these consequences of industrial transformation since the last three industrial revolutions. All three past industrial revolutions have made it possible to create more jobs than technological developments have eliminated. More significant growth was achieved, which led to a reduction in the poverty rate and enabled people to lead a better life. The question is, however, what will the industrial revolution bring to society, which will have or already has a strong influence on production, which today accounts for 70\% of GDP on a global scale? Governments, together with companies, will probably have to find solutions for workers in sustainable social policy programs, whose training and experience will become irrelevant due to advanced technological developments [83]. In 2020, for example, it announced the layoff of 
only Mercedes Benz 15,000 employees by 2022, which is due to the digital transformation of production and the attempt to adapt production processes to the production of electric cars. The entire automotive industry announced the layoff of 80,000 employees for a short period of three years (2020-2023). As we can see, the social and economic impact of the digital transformation will be decisive. In the entire value chain (not only in the automotive industry but also in other sectors), the middleman will become superfluous [81].

The introduction of sustainability into the traditional concept of business operations is based on a thematic approach (theme business). For example, sustainability is connected to climate change, diversity and the awareness of corporate leaders that human rights must be respected (these are the rights of employees in global supply chains). In Europe and Asia, (especially in China) both business schools and companies are increasingly aware of the importance of taking sustainability into account in business. Business schools so try to the introduce the new technologies and products that do not pollute the environment and use renewable energy and through sustainable business models (e.g. circular economy, green transformation, social entrepreneurship) that include business ethics. On the other hand, the US does not pursue sustainable concepts and does not invest in the training of professionals in this field [84]. The People's Republic of China, however, has addressed the problem of how to solve environmental problems resulting from rapid economic growth. With increasing investment in research and development, they want to become world leaders in the development of environmental technologies. China, for example, already has a dominant share of environmental patent applications like Europe or North America. China has thus already overtaken the USA as the world's leading exporter of environmental technologies in terms of battery development, automobile production and solar technologies [85]. The China Corporate Responsibility and Sustainability Council notes, however, that China is still confronted with social and economic constraints resulting from its rapid economic development. For example, a large number of people moved from the countryside to more than 10 million cities, which are now confronted with unregulated sewage, traffic problems, too high levels of pollution of the atmosphere and water resources, etc. China needs to address social and environmental issues sustainably. Otherwise, it will increase costs and damage the reputation and growth of companies in China [86].

The importance of digitizing the human environment and business became even more critical when the outbreak of COVID-19 showed that human life must be further digitized. The need to establish creative online content and online business services are increasingly coming to the fore. The most digitized cities are London, Paris, San Francisco, Los Angeles and Singapore. Part of the answer what is a smart city probably lies in the Internet of Things, which is part of the idea of intelligent technologies or even a link between them. Remote-controlled operations, technological innovations and self-propelled cars are only a part of the whole story. Internet of Things provides more data that can help improve many aspects of our daily lives. They can even help create jobs. For example, according to Forbes, Barcelona has saved $€ 75$ million a year and created 47,000 jobs in technology development by providing high-speed Internet connections and integrating smart lighting, smart irrigation and parking management. In Amsterdam, the city uses the Internet of Things-based infrastructure to monitor traffic flow, energy consumption and public safety using real-time data. In Boston and Baltimore, smart garbage bins are being developed that indicate how full they are and determine the most efficient collection route for sanitary workers [87]. 
The appearance of COVID-19 is likely to have a significant impact on ensuring that a sustainable city and smart city are not mutually exclusive. The concept of a smart city is a model of developing a sustainable city. When we talk about the emergence of the sustainable cities, their development may take longer if it is based on the use of traditional planning tools, without the necessary high-tech solutions that are part of the smart city. A smart city (e.g. green Vienna or Lisbon projects) has become more sustainable (e.g. sensors controls the energy and water consumption and provide better living conditions (more green areas), which it achieves by implementing high-tech solutions in the urban fabric. The emergence of COVID-19 is changing public transport in the cities and cities have launched in spring 2020 projects to promote walking and cycling. With the increase in e-bikes, scooters and transport, the focus has shifted to reach. Mayors around the world are already taking the opportunity to redesign lanes for pedestrians and cyclists. It is expected that the carsharing model will expand in cities. The relationship between illness and density is also perceived as complex. Some high-density cities, such as Seoul, Taiwan and Singapore, have suppressed mainly the virus. In other lower-density cities, such in the Italian region Lombardy and U.S. country Louisiana, the virus has spread rapidly. London now has a much lower rate of infection than the north-east of Great Britain [88].

A study published in The Economist [89] shows that on a global level, residents not only want to be informed about the course of these processes but also want to participate in the formulation of urban development policies. At the global level, companies involved in these projects also expect cities to draw up long-term development plans. The main differences between the population's expectations of urban development occur at the micro-level. In cities such as Los Angeles, San Francisco, Dubai and Zurich, residents need to develop a smart city initiative that supports the development of citizen participation processes in the preparation and adoption of the city budget. In London, Riyadh, Stockholm and Sydney, residents expect more long-term planning. In less developed cities like Johannesburg and Mumbai, people want to create initiatives that promote the development of small businesses. In São Paulo and Singapore, residents want to ensure fairer access to smart services, while in Hong Kong São Paulo and Singapore, residents are most in favor of better protection of personal data.

\subsection{The comparison of the analysis's results}

The analyses of both types of literature, both scientific and professional, show that there are common topics they write about, which are related to the field of clean production, emissions, renewable energy, climate change, sustainable investments and corporate sustainability. An urgent global issue that extends all over the world is the promotion of energy-saving technologies and reduction of carbon dioxide emissions [34].

We also looked for differences in the topics covered by the literature of different types. We found that the scientific literature focuses more on changes in business models, production processes and technologies that enable sustainable development. Newspapers and magazines articles write more about sustainable or green investment, sustainable standards and sustainable reporting. It is going for thematizes that are directly important for current sustainable business development and encouraging the research and development of cleaner and smarter technologies and processes.

The relevant and current theme nowadays is oriented towards COVID-19 and its impact on the economy and society. The newspapers and some latest research journals include articles of the COVID-19 outbreak and its effect on the economy and the environment. Indeed, the outbreak of the virus brings new thinking about the reorganization of the complex relationships between consumers, businesses and the state [90]. The question is whether, in rescuing the economy, we will unreasonably 
seek to return to the old patterns as quickly as possible, or whether we will use the moment to reshape and restructure the national economy. It offers a unique opportunity to solve two crises at once, with prudent behavior and wise action [91]. The response to the health and economic crisis can be enhanced by tackling the environmental crisis, which can also disrupt the food chain [92]. The latter, however, first requires an ambitious restructuring plan from a linear to a circular economy. The ideas of green transformation are not entirely new at such times [93]. During the previous crisis, state aid for the car giants was made conditional on their moving to stricter emission standards. However, the current situation allows the implementation of much more ambitious plans compared to then, as the social climate is much more favorable today than it was in 2008 [94]. Companies will have to thoroughly rethink their existing business models, organizational structure and the way they work during and after the crisis. Intertwined global supply chains, marketing approaches that respond to pre-crisis consumer habits, and mandatory physical presence in the workplace are just some of the critical factors already under discussion and the reason for the forthcoming transformation of the business environment. The coming weeks and months will bring many new insights into labor productivity as one of the critical factors in production. Management discussions will revolve around the possibilities and opportunities of the digital transformation of companies. Internal policies will adapt to the new situation in the areas of business travel, contractual relations and security. The wait for state aid will not solve several challenges, so companies must use this time to make a radical transformation. The latter requires a thorough reflection on the strategy of the company and its role in society as a whole, the business and profit model and, last but not least, the role of employees in this process $[95,96]$.

Finally, the role of the states themselves is, and remains, extremely important. They will bear a considerable part of the financial burden of the crisis, so timely planning and intelligent conditioning of measures are crucial. Rescuing companies cannot and should not be aimed at returning to a precrisis state. The latter is not only impossible because the world has changed considerably in a few months, but also pointless because we could miss one of the few opportunities for an extensive green, the circular transformation of the economy. State-sponsored financial instruments should, therefore, be based on the principles of green financing, grants should include a commitment to meet ambitious environmental standards, and measuring the success of a national rescue package should be based not only on traditional macroeconomic indicators but also on broader social and environmental impacts [97]. Sustainable development and recycling must become more than just theoretical concepts, which means that they must be operationalized through sector-specific and fact-based measures. Countries can build on existing commitments and solutions; within the EU these include, for example, the efforts of European climate and energy policy or reporting and taxonomy standards for sustainable activities in the EU [98].

\section{Conclusion}

According to the analyzed thematic were identified and explained the most critical and recent global socio-economic and technological trends related to the I4.0 and challenges for sustainable development. We have conducted the concept analysis of the scientific papers as well as articles published in the news. The results revealed that there are some overlapping between the concepts that emerged from the newspaper and scientific journal articles, such as various aspects of sustainability. However, newspaper articles investigate also some concepts that are substantially different from scientific journal articles, and these are mostly related to business and company aspects.

The present research can serve a variety of stakeholders. Scientists can learn which areas are less researched in the field of I 4.0 and sustainability, and it would be worth exploring them in more depth. Policymakers can become aware of topics in the field of sustainability, which are most pressing and worth reading. Results can also serve managers in the private and public sector to integrate sustainable practices in business. For this reason, manufacturing organizations need to improve their sustainable business performance. Therefore, sustainability can ensure that I4.0 delivers sustainability functions effectively. 
Based on the research carried out, we can assess the gaps in knowledge regarding the articles selection procedures, the characteristics of the analysis (see Section 2.3) and the purpose of the results analyzed. The significant limitation of this research is the articles are processed in a certain period and a specific article database and because of that they probably do not contain all scientific research and expert opinions on the selected research content. The main thing is that the results of the analysis give us an insight into the connections and relationships between Industry 4.0 and sustainability.

For future studies, several methodological approaches should be used to contrast and compare different methods. The application of primary research with experts in different countries using quantitative and qualitative research methods could have led to a deeper understanding of the research problems, such as: if we had conducted a Delphi study with experts from different I4.0 and sustainability fields, this study could have benefited from the different data sources; the analysis of the success of the emergence of green technologies and sustainable business models; or longitudinal research on the impact of Industry 4.0 technologies on social changes in society and their influence on social processes in general.

Conflicts of Interest: The author declares no conflict of interest.

\section{References}

1. United Nations. Transforming our world: the 2030 Agenda for Sustainable Development. Available online: https://sustainabledevelopment.un.org/post2015/transformingourworld/publication (accessed on 3 September 2020).

2. Ejsmont, K.; Gladysz, B.; Kluczek, A. Impact of Industry 4.0 on Sustainability-Bibliometric Literature Review. Sust. 2020, 12,14, 5650.

3. Piccarozzi, M.; Aquilani, B.; Gatti, C. Industry 4.0 in management studies: A systematic literature review. Sust. 2018, 10,10, 3821.

4. Jerman, A.; Pejić Bach, M.; Bertoncelj, A. A bibliometric and topic analysis on future competences at smart factories. Mach. 2018, 6,3, 41.

5. Jerman, A.; Erenda, I.; Bertoncelj, A. The influence of critical factors on business model at a smart factory: A case study. Bus. Syst. Res. J. 2019, 10,1, 42-52.

6. Birkel, H. S.; Veile, J. W.; Müller, J. M.; Hartmann, E.; Voigt, K. I. Development of a risk framework for Industry 4.0 in the context of sustainability for established manufacturers. Sust. 2019, 11,2, 384.

7. Müller, J. M.; Däschle, S. Business model innovation of industry 4.0 solution providers towards customer process innovation. Proc. 2018, 6,12, 260.

8. Oztemel, E.; Gursev, S. Literature review of Industry 4.0 and related technologies. J. of Inf. Man. 2020, 31,1, 127-182.

9. Lööw, J.; Abrahamsson, L.; Johansson, J. Mining 4.0-The impact of new technology from a work place perspective. Min. Met. E Expl. 2019, 36,4, 701-707.

10. Xu, S.; Stienmetz, J.; Ashton. How will service robots redefine leadership in hotel management? A Delphi approach. Int. J. of Con. Hos. Man. 2020, 32,6, 2217-2237.

11. Baldwin, R. The globotics upheaval: Globalization, robotics, and the future of work. Oxford University Press; Oxford, UK, 2019.

12. Nuvolari, A. Understanding successive industrial revolutions: A “development block" approach. Env. Inn. and Soc. Trans. 2019, 32, 33-44.

13. Ghobakhloo, M. Industry 4.0, digitization, and opportunities for sustainability. J. of Clean. Prod. 2020, 252, 119869

14. Cheng, M; Edwards, D. A comparative automated content analysis approach on the review of the sharing economy discourse in tourism and hospitality. Curr. Iss. in Tour. 2017, 22, 35-49.

15. Pucihar, A. The digital transformation journey: Content analysis of Electronic Markets articles and Bled eConference proceedings from 2012 to 2019. El. Mar. 2020, 30, 29-37.

16. Bednarek, M. Evaluation in media discourse: Analysis of a newspaper corpus. Continuum; London, UK, 2006.

17. McCombs, B. L. The learner-centered model: Implications for research approaches. In Interdisciplinary handbook of the person-centered approach; White-Cornelius H.D.J.; Pitrik-Motschnikg, R.; Lux, M., Eds.; Springer, New York, NY, 2013, pp. 335-352. 
18. Schmidt, A.; Ivanova, A.; Schäfer, M. S. Media attention for climate change around the world: A comparative analysis of newspaper coverage in 27 countries. Global Env. Ch. 2013, 23,5, 1233-1248.

19. Schweinsberg, S.; Darcy, S.; Cheng, M. The agenda setting power of news media in framing the future role of tourism in protected areas. Tour. Man. 2017, 62, 241-252.

20. Thetela, P. Evaluated entities and parameters of value in academic research articles. Eng. for Spec. Purp. 1997, 16,2, 101-118.

21. Systematic Literature Review from 2000-2016. Sust. 2018, 10,5, 1627.

22. Moher, D.; Liberati, A.; Tetzlaff, J.; Altman, D. G.; Prisma Group. Preferred reporting items for systematic reviews and meta-analyses: the PRISMA statement. PLoS Med. 2009, 6,7, e1000097.

23. Proquest. News \& Newspapers. Available online: https://about.proquest.com/libraries/academic/newsnewspapers/?page=2 (accessed on 18 August 2020).

24. Blei, D. M. Topic modeling and digital humanities. J. of Dig. Hum. 2012, 2,1, 8-11.

25. Nunez-Mir, G. C.; Iannone III, B. V.; Pijanowski, B. C.; Kong, N.; Fei, S. Automated content analysis: addressing the big literature challenge in ecology and evolution. Meth. in Ec. and Ev. 2016, 7,11, 1262-1272.

26. Usai, A.; Pironti, M.; Mital, M.; Mejri, C. A. Knowledge discovery out of text data: a systematic review via text mining. J. of KM 2018, 22, 7, 1471-1488.

27. McNamara, D. S.; Graesser, A. C.; McCarthy, P. M.; Cai, Z. Automated evaluation of text and discourse with Coh-Metrix; Cambridge: University Press, New York, NY, 2014.

28. Blaschke, T. Object based image analysis for remote sensing. ISPRS J. of Photogr. and Rem. Sens. 2010, 65, 216

29. Krippendorff, K. Content Analysis: An Introduction to Its Methodology; Sage Publications: Thousand Oaks, CA, USA, 2013.

30. Vaismoradi, M.; Turunen, H.; Bondas, T. Content analysis and thematic analysis: Implications for conducting a qualitative descriptive study. Nurs. Health Sci. 2013, 15, 398-405

31. Pejić Bach, M.; Krstić, Ž.; Seljan, S.; Turulja, L. Text mining for big data analysis in financial sector: A literature review. Sust. 2019, 11,5, 1277.

32. Leximancer (2020). Leximancer User Guide. Available online: https://info.leximancer.com/ (accessed on 2 May 2020).

33. Beier, G.; Niehoff, S.; Ziems, T.; Xue, B. Sustainability aspects of a digitalized industry-A comparative study from China and Germany. Int. J. of Prec. Eng. and Man.-Gr. Tech. 2017, 4,2, 227-234.

34. Fujii, M.; Fujita, T.; Dong, L.; Lu, C.; Geng, Y.; Behera, S. K.; ... Chiu, A. S. F. Possibility of developing lowcarbon industries through urban symbiosis in Asian cities. J. of Clean. Prod. 2016, 114, 376-386.

35. Beier, G.; Ullrich, A.; Niehoff, S.; Reißig, M.; Habich, M. Industry 4.0: How it is defined from a sociotechnical perspective and how much sustainability it includes-A literature review. J. of Clean. Prod. 2020, 259, 120856.

36. Lytos, A.; Lagkas, T.; Sarigiannidis, P.; Zervakis, M.; Livanos, G. Towards smart farming: Systems, frameworks and exploitation of multiple sources. Comp. Netw. 2020, 172, 107147.

37. Mocnej, J.; Pekar, A.; Seah, W. K.; Papcun, P.; Kajati, E.; Cupkova, D.; ...; Zolotova, I. Quality-enabled decentralized IoT architecture with efficient resources utilization. Rob. and Comp.-Int. Man. 2000, 67, 102001.

38. Braccini, A. M.; Margherita, E. G. Exploring organizational sustainability of industry 4.0 under the triple bottom line: The case of a manufacturing company. Sust. 2019, 11,1, 36.

39. Xu, L. D.; Xu, E. L.; Li, L. Industry 4.0: state of the art and future trends. Int. J. of Prod. Res. 2018, 56,8, 29412962.

40. Altay, N.; Gunasekaran, A.; Dubey, R.; Childe, S. J. Agility and resilience as antecedents of supply chain performance under moderating effects of organizational culture within the humanitarian setting: a dynamic capability view. Prod. Plan. E Cont. 2018, 29,14, 1158-1174.

41. Papadopoulos, T.; Gunasekaran, A.; Dubey, R.; Altay, N.; Childe, S. J.; Fosso-Wamba, S. The role of Big Data in explaining disaster resilience in supply chains for sustainability. J. of Clean. Prod. 2017, 142, 11081118.

42. Frank, A. G.; Dalenogare, L. S.; Ayala, N. F. Industry 4.0 technologies: Implementation patterns in manufacturing companies. Int. J. of Prod. Econ. 2019, 210, 15-26.

43. Yadav, G.; Luthra, S.; Jakhar, S. K.; Mangla, S. K.; Rai, D. P. A framework to overcome sustainable supply chain challenges through solution measures of industry 4.0 and circular economy: An automotive case. J. of Clean. Prod. 2020, 254, 120112. 
44. de Sousa Jabbour, A. B. L.; Jabbour, C. J. C.; Foropon, C.; Godinho Filho, M. When titans meet-Can industry 4.0 revolutionize the environmentally-sustainable manufacturing wave? The role of critical success factors. Tech. For. and Soc. Ch. 2018, 132, 18-25.

45. Reddy, N.; Chen, L.; Zhang, Y.; Yang, Y. Reducing environmental pollution of the textile industry using keratin as alternative sizing agent to poly (vinyl alcohol). J. of Clean. Prod. 2014, 65, 561-567.

46. Stock, T.; Obenaus, M.; Kunz, S.; Kohl, H. Industry 4.0 as enabler for a sustainable development: A qualitative assessment of its ecological and social potential. Process Safety and Env. Prot. 2018, 118, 254-267.

47. Kaymak, T.; Bektas, E. Corporate social responsibility and governance: Information disclosure in multinational corporations. Corp. Soc. Resp. and Env. Man. 2017, 24,6, 555-569.

48. Kantabutra, S.; Ketprapakorn, N. Toward a theory of corporate sustainability: A theoretical integration and exploration. J. of Clean. Prod. 2020, 270, 122292.

49. Tozanlı, Ö.; Kongar, E.; Gupta, S. M. Trade-in-to-upgrade as a marketing strategy in disassembly-to-order systems at the edge of blockchain technology. Int. J. of Prod. Res. 2020, doi: 10.1016/j.emj.2020.04.010.

50. Luthra, S.; Kumar, A.; Zavadskas, E. K.; Mangla, S. K.; Garza-Reyes, J. A. Industry 4.0 as an enabler of sustainability diffusion in supply chain: an analysis of influential strength of drivers in an emerging economy. Int. J. of Prod. Res. 2020, 58,5, 1505-1521.

51. Ramakrishna, S., Ngowi, A., Jager, H. D., Awuzie, B. O. Emerging Industrial Revolution: Symbiosis of Industry 4.0 and Circular Economy: The Role of Universities. Sc., Tech. and Soc., 2020, doi: 10.1177/0971721820912918.

52. Nascimento, D. L. M.; Alencastro, V., Quelhas, O. L. G.; Caiado, R. G. G.; Garza-Reyes, J. A.; Rocha-Lona, L.; Tortorella, G. Exploring Industry 4.0 technologies to enable circular economy practices in a manufacturing context. J, of Man. Tech. Man. 2019, 30,3, 607-627.

53. Munsamy, M.; Telukdarie, A.; Fresner, J. Business process centric energy modelling. Bus. Proc. Man. J. 2019, 25, 7, 1867-1890.

54. Kohtamäki, M.; Parida; V.; Oghazi, P.; Gebauer, H.; Baines, T. Digital servitization business models in ecosystems: A theory of the firm. J. of Bus. Res. 2019, 104, 380-392.

55. Santana, M.; Cobo-Martín, M. J. What is the future of work? A science mapping analysis. Eu. Man. J. 2020, doi: 10.1016/j.emj.2020.04.010.

56. Li,G.; Hou, Y.; Wu, A. Fourth Industrial Revolution: technological drivers, impacts and coping methods. Ch. Ge. Sc. 2017, 27,4, 626-637.

57. Ritter, T.; Pedersen, C. L. Digitisation capability and the digitalization of business models in business-tobusiness firms: Past, present, and future. Ind. Mar. Man. 2020, 86, 180-190.

58. Obiso, J. J. A.; Himang, C. M.; Ocampo, L. A.; Bongo, M. F.; Caballes, S. A. A.; Abellana, D. P. M.; ... ;Jr R. A. Management of Industry 4.0-reviewing intrinsic and extrinsic adoption drivers and barriers. Int. J. of Tech. Man. 2019, 81,3-4, 210-257.

59. Peura, P.; Haapanen, A.; Reini, K.; Törmä, H. Regional impacts of sustainable energy in western Finland. J. of Clean. Prod. 2018, 187, 85-97.

60. Ranängen, H.; Lindman, A. A path towards sustainability for the Nordic mining industry. J. of Clean. Prod. 2017, 151, 43-52.

61. Lu, C. J.; Yang, C. T.; Yen, H. F. Stackelberg game approach for sustainable production-inventory model with collaborative investment in technology for reducing carbon emissions. J. of Clean. Prod. 2020, 270, 121963.

62. Tsai, W. H.; Lu, Y. H. A framework of production planning and control with carbon tax under industry 4.0. Sust. 2018, 10,9, 3221.

63. Tsai, W. H.; Jhong, S. Y. Production decision model with carbon tax for the knitted footwear industry under activity-based costing. J. of Clean. Prod. 2019, 207, 1150-1162.

64. Aureli, S.; Gigli, S.; Medei, R.; Supino, E. The value relevance of environmental, social, and governance disclosure: Evidence from Dow Jones Sustainability World Index listed companies. CSR and Env. Man. 2020, 27,1, 43-52.

65. Lali, L. Beyond the 3 Rs: How can Singapore move forward on sustainability? The Business Times, 30 May. 2020 Available online: https://www.businesstimes.com.sg/brunch/beyond-the-3-rs-how-can-singaporemove-forward-on-sustainability (accessed 6 July 2020).

66. Stevenson, D. Are ESG and sustainability the new alpha mantra? Financial Time, 1 April 2020. Available online: https://www.ft.com/content/6cee0b48-7760-46a5-9759-243aaaff7f8a (accessed 10 July 2020). 
67. Gibbens, S. 15 ways the Trump administration has changed environmental policies. National Geographics, 1 February 2019. Available online: https://www.nationalgeographic.com/environment/2019/02/15-waystrump-administration-impacted-environment/ (accessed 9 July 2020).

68. Khan, M. Brussels ramps up emissions goals as MEPs declare 'climate emergency'. Financial Time, 28 November 2019. Available online: https://www.ft.com/content/cadca90e-11da-11ea-a7e6-62bf4f9e548a.

69. Wincuinas, J., ed. Sustainable and actionable: A study of asset-owner priorities for ESG investing in Asia. Available online: https://eiuperspectives.economist.com/sustainability/sustainable-and-actionablestudy-asset-owner-priorities-esg-investing-asia (accessed 9 July 2020).

70. Hay, G. Breakingviews - Sustainable investing will wind up in the dock. Reuters, 2019. Available online: https://www.reuters.com/article/us-global-sustainability-breakingviews-idUSKBN1YZOPC (accessed 7 July 2020).

71. Landrum, S. Millennials driving brands to practice socially responsible marketing. Forbes Magazin, 17 March 2017. Available online: https://www.forbes.com/sites/sarahlandrum/2017/03/17/millennialsdriving-brands-to-practice-socially-responsible-marketing/ (accessed 5 July 2020).

72. Wong, K. How to be a more conscious consumer, even if you're on a budget. The New York Times, 1 October 2019. Available online: https://www.nytimes.com/2019/10/01/smarter-living/sustainabile-shoppingconscious-consumer.html (accessed 7 July 2020).

73. The Economist. Big business is beginning to accept broader social responsibilities. Available online: https://deliverchange.economist.com/article/big-business-beginning-accept-broader-socialresponsibilities/ (accessed 9. July 2020).

74. Jessop, S. Deutsche Bank targets 200 billion euros of sustainable investment by 2025. Reuters, 2020. Avaiable online: https://www.reuters.com/article/us-deutsche-bank-sustainability-idUSKBN22P132 (accessed 7. July 2020).

75. Neghaiwi Hughes, B. Credit Suisse sets up investment banking sustainability advisory. Reuters, 2019. Available online: https://uk.reuters.com/article/uk-credit-suisse-gp-sustainability/credit-suisse-sets-upinvestment-banking-sustainability-advisory-idUKKBN21L2Z6 (accessed 9. July 2020).

76. Gitlin, M.J. California set to ban all heavy diesel trucks and vans by 2045. Ars Technica, 26 June 2020 Available online: https://arstechnica.com/cars/2020/06/california-set-to-ban-all-heavy-diesel-trucks-andvans-by-2045/ (accessed 9. July 2020).

77. Thomasson, E. Zalando to push 'sustainable' fashion, cut emissions. Reuters, 2019. Available online: https://www.reuters.com/article/us-zalando-environment/zalando-to-push-sustainable-fashion-cutemissions-idUSKBN1X90X8 (accessed 9. July 2020).

78. Cobburn, C. Why industry is going green on the quiet. The Guardian, 8 September 2019. Available online: https://www.theguardian.com/science/2019/sep/08/producers-keep-sustainable-practices-secret (accessed 9. July 2020).

79. Washington Post. Transcript: A world in balance - solutions for sustainability. Available online: https://www.washingtonpost.com/blogs/post-live/wp/2017/11/16/transcript-a-world-in-balance-solutionsfor-sustainability/ (accessed 9. July 2020).

80. Vaughan, A. BP aims to invest more in renewables and clean energy. The Guardian, 6 February 2018. Available online: https://www.theguardian.com/business/2018/feb/06/bp-aims-to-invest-more-inrenewables-and-clean-energy (accessed 9 July 2020).

81. Sonnemaker, T. Mercedes-Benz parent company Daimler is preparing to lay off 15,000 workers as it tries to adapt to electric cars. Business Insider, 10 February 2020. Available online: https://www.businessinsider.com/mercedes-benz-parent-daimler-reportedly-planning-15000-layoffs2020-2 (accessed 9 July 2020).

82. Angel, M. Corrected-Nestle invests $\$ 45 \mathrm{mln}$ a year in cocoa sustainability. Reuters, 2019. Available online: retrieved from https://in.reuters.com/article/nestle-cocoa-sustainability-idINL8N28J4Z0 (accessed 8 July 2020).

83. Monaghan, A. Businesses must address impact of next industrial revolution, says Siemens boss. The Guardian, 16 July 2018. Available online: https://www.theguardian.com/business/2018/jul/15/globalworkforce-will-be-decimated-by-fourth-revolution-says-siemens-boss accessed 8 July 2020).

84. Thomspon, J. 2020. Big investors' sustainability push drives demand for environmental expertise. Financial Time. Retrieved from https://www.ft.com/content/362fdc36-3b97-11ea-b84f-a62c46f39bc2 (accessed 9 July 2020). 
85. Davidson, H. China on track to lead in renewables as US retreats, report says. The Guardian, 10 January 2018. Available online: https:/www.theguardian.com/environment/2018/jan/10/china-on-track-to-lead-inrenewables-as-us-retreats-report-says (9 July 2020).

86. Friedman, R. Sustainability: Moving the conversation forward. The Economist, 3 December 2018. Available online: Inteligence unit, retrieved from https://eiuperspectives.economist.com/sustainability/sustainability-moving-conversation-forward (accessed 10 July 2020).

87. McFarlane, C. Are Smart Cities The Pathway To Blockchain And Cryptocurrency Adoption? The Forbes, 18 October 2019. Available online: https://www.forbes.com/sites/chrissamcfarlane/2019/10/18/are-smartcities-the-pathway-to-blockchain-and-cryptocurrency-adoption/\#7a10b7846093 (accessed 5 July 2020).

88. Rogers, B. Cities are not dead - they will get younger. Financial Times, 24 May 2020. Available online: https://www.ft.com/content/d4fff7a2-9b63-11ea-871b-edeb99a20c6e (accessed 9 July 2020).

89. Gold, M. Accelerating urban intelligence: People, business and the cities of tomorrow. The Economist, 27 April 2019 Intelligence Unit. Available online: https:/eiuperspectives.economist.com/technologyinnovation/accelerating-urban-intelligence-people-business-and-cities-tomorrow/whitepaper/accelerating-urban-intelligence-people-business-and-cities-tomorrow (accessed 7. July 2020).

90. Rudolph, C.W.; Allan, B.; Clark, M., Hertel, G., Hirschi, A., Kunze, F., Shockley, K., Shoss, M., Sonnentag, S., Zacher, H. 2020. Pandemics: Implications for research and practice. Ind and Org Psy: Persp on Sc and Pr. In press.

91. Van den Heuvel, M. How COVID turned a spotlight on weak worker rights. The Harvard Gazzete, 23 June 2020. Available online: https://news.harvard.edu/gazette/story/2020/06/labor-law-experts-discussworkers-rights-in-covid-19/

92. Gustin, G. Think Covid-19 Disrupted the Food Chain? Wait and See What Climate Change Will Do. Inside climate news, 7 July 2020. Available online: https://insideclimatenews.org/news/06072020/coronavirusagriculture-food-chain-future-climate-change (accessed 7. July 2020).

93. Ghisellini, P., Cialani, C., Ulgiati, S. 2016. A review on circular economy: the expected transition to a balanced interplay of environmental and economic systems. J. of Clean. Prod. 2016, 114, 11-32.

94. Harari, Y.N. The world after coronavirus. The Financial Times, 20 March 2020. Available online: https://www.ft.com/content/19d90308-6858-11ea-a3c9-1fe6fedcca75 (accessed 17. July 2020).

95. Bapuji, H.; de Bakker, F. G.; Brown, J. A.; Higgins, C.; Rehbein, K.; Spicer, A. Business and Society Research in Times of the Corona Crisis. Buss. and Soc. 2020, 59,6, 1067-1078.

96. Hua, J.; Shaw, R. Coronavirus (Covid-19) "infodemic" and emerging issues through a data lens: The case of China. Int. J. of Env. Res. and Pub. H. 2020, 17, 7, 2309.

97. Boot, A.W.; Carletti, E.; Kotz, H. H.; Krahnen, J.P.; Pelizzon, L., Subrahmanyam, Corona and Financial Stability 3.0: Try equity-risk sharing for companies, large and small. SAFE Policy Letter 81, 2020. Available online: https://safe-frankfurt.de/policy-center/policy-publications/policy-publdetailsview/publicationname/corona-and-financial-stability-30-try-equity-risk-sharing-for-companieslarge-and-small.html /accessed 4 September 2020).

98. Trippel, E. How green is green enough? The changing landscape of financing a sustainable European economy. ERA Forum 2020, doi: 10.1007/s12027-020-00611-z. 